Journal of Animal and Veterinary Advances 18 (8): 256-259, 2019

ISSN: 1680-5593

(C) Medwell Journals, 2019

\title{
Impact of Some Factors on Profitability of Sheep Farms under Egyptian Conditions
}

\author{
Ibrahim A. Mostafa \\ Department of Animal Husbandry and Animal Wealth Development, \\ Faculty of Veterinary Medicine, University of Sadat City, Sadat, Egypt
}

\begin{abstract}
The aim of this study is economic evaluation and investigation of some factors effect as season, demo-graphic characters (manager characters) and some productive and reproductive disorders in sheep production farms under Egyptian conditions. Data were randomly collected from commercial sheep farms from different localities in Menofia governorate that located in South of Nile delta in Egypt. The data include season that grouped to (cold season) extended from 21 September-20 March and (warm season) from 21 March-20 September to determine its effect on birth weight, litter size and kidding interval. The data were collected summarized and analyzed by statistical computer program (SPSS/PC, 16).
\end{abstract}

Key words: Sheep production farms, manager characters, economic losses, manager characters, educatinal level, production change

\section{INTRODUCTION}

In developing countries sheep considered an important livestock species due to their grazing habits and their ability to grow on plants that not be eaten by other livestock species (Odunsi et al., 2005). Sheep provide enough meat quantity for household consumption, so, considered as poor man's cow (Seyoum, 1992). Small size farmers can earn supplementary income by small ruminant production (Okunlola, 2000). In Egypt the total sheep population is $4,200,000$ heads and contributes $6 \%$ of the total red meet produced. Rahmani, Ossimi and Barki are the main breeds in Egypt (Galal et al., 2005).

Egyptian sheep are subtropical fat-tailed sheep characterized by ability to breed all year round and satisfactory fertility but have low prolificacy and growth rate (Al-Azzawi et al., 2006). Farm animal growth traits are determined not only by an animal's genetic potential for growth but also by permanent and temporary environmental effects (Ebangi et al., 1996).

Sheep producers strive to maximize profitability of the flock through increase flock productivity which is a complex trait and is related to ewe productivity. Fertility prolificacy, lamb survival and lamb weaning weight are the main factors that determine both flock and ewe productivity. All of these factors may be affected by flock characteristics such as breed type and ewe age as well as management (Long et al., 1989). The environmental conditions often result in seasonal variation in meat prices. In the semi-arid regions where a large proportion of sheep is located there is a large difference in the availability of feed amount between seasons. Therefore, during the dry seasons producers are forced to reduce the total number of animal units due to feed shortages this creates an excess supply that in turn causes a decrease in prices (De Queiroz et al., 1986).
Management skills and production systems become more sophisticated and this is one of the most serious constraints to achieving higher production rates. There is a special need for training and technology transfer that would cover all aspects of production management (Safilios-Rothschild, 1983).

Lack of skilled labor is often the main cause of lack of improvement in the productivity of sheep. Most of the labor is provided by the family. The person responsible for the day-to-day care varies widely depending on the production system (extensive or intensive), the number of animals, cultural factors and other reasons. Young children usually take care of small or backyard flocks and the role of women varies considerably according to the country, region, ethnic groups, etc., as not only take care of the animals but also own them and market them in many places (Safilios-Rothschild, 1983).

If the farm includes crops, sheep production would be affected by seasonal labor especially during planting and harvesting as available labor is used in the fields. There is empirical evidence that sheep production in certain regions is very sensitive to price and weather condition changes (Souza et al., 1984).

Different sheep breeds evolved a variety of reproductive strategies to suit the wide range of environments developed in. Increased body temperature can lower ewe's reproductive rate by decreasing ovulation rate, increasing embryonic mortality or by delaying heat cycles (Armbruster et al., 1991).

\section{MATERIALS AND METHODS}

Study area: The data for this study were obtained from 10 large commercial sheep farms at Menofia Province during period extended from January-December 2017 on random samples of sheep farms. Menofia is an Egyptian 
Province in the South of the Nile Delta and located North of the Egyptian Capital Cairo. About half of the province area located in between the two branches of the Nile, so, the main economic activity in the province is agriculture where the fertile soil and abundant water for irrigation.

Data collection and classification: The data for this study collected from commercial sheep farms at Menofia Province from a cross-sectional and longitudinal field survey. The data was collected by two methods from the accurate records and from the structured questionnaire method which established by the researcher, according to Omar (2009). Sheep flocks were visited twice at least, once in summer and the other in winter along the course of study.

The data classified according to season of kidding into warm season that extended from "21 March-20 September" and cold season that extended from "21 September-20 March” (Atallah, 1997).

The collected data was classified into different parameters to evaluate the productive, economic efficiency as follows:

\section{Production and managemental data:}

- Production season

- $\quad$ Litter size and birth weight/kg

- $\quad$ Types and amount of feed consumed per year

- $\quad$ Age at first kidding and kidding interval

- Demo-graphic information (owner age, education level)

\section{Financial data}

\section{Costs of production}

Fixed Costs (TFC): It includes the costs of depreciation of sheep, buildings, equipment and machines. The depreciation rate calculated for the building as depreciated within 25 years and equipment and machines within 5 years. The animal depreciation calculated by straight line method according to the useful productive life "years" (Atallah, 1997; Omar, 2009).

Variable Costs (TVC): Included the costs of drugs, vaccines, disinfectants, veterinary supervision, feed and concentrates cost, semen cost, labor cost and other miscellaneous costs.

Returns: Included the Total Returns (TR) from sales of meat, newborn added to the flock values or sales, animal and manure according to the market prices during study period. And the Net Returns (NR) that calculated by the following equation $(\mathrm{NR}=\mathrm{TR}-\mathrm{TC})$.

Statistical analysis: The data collected, summarized and analyzed using (SPSS/PC, 2016) computer program to test the effect of some factors as season and labor on profitability of sheep farms using t-test to compare of the means. Data were expressed as means and standard errors.

\section{RESULTS AND DISCUSSION}

Impact of season on birth weight and litter size: Table 1 showed that, there is a significant difference $(p<0.01)$ between the mean values of birth weight and litter size of newborn lambs in the two seasons of birth. As in warm season the mean value of birth weight and litter size were higher 2.94, $1.61 \mathrm{~kg}$ and lower in cold season 2.04, $1.16 \mathrm{~kg}$, respectively, this may be owed to good environmental conditions and availability of good quality feed stuffs in spring season. The results may agree with (De Queiroz et al., 1986) who show a significant effect of season on birth weight and litter size.

Impact of season on age at 1st kidding and kidding interval: Results in Table 2 revealed that there was a significant difference $(\mathrm{p}<0.01)$ of age at 1 st kidding and kidding interval according to season as age at 1st kidding was 13.48 months for cold and 10.37 months for warm season, respectively. Moreover, the kidding interval was 8.16 months for cold and 9.13 months for warm season, respectively. These results agreed with that concluded a significant relationship between kidding season and reproductive performance ewe.

Enterprise budget for sheep flocks: One of the best ways to estimate the profitability of small ruminant enterprise is to do an enterprise budget. An enterprise budget is a simple listing of income and expenses. According to Table 3, the most important variable inputs in small ruminant production were labor, feed and veterinary inputs, the mean value of revenue was 39456 EGP per year/flock formed of 20 heads. Moreover, the total cost was 42297.36 EGP per year/flock. Furthermore, the feed cost represents $42.5 \%$ of variable cost and labour represents $47.2 \%$ of variable cost also the benefit cost

Table 1: Effect of season on birth weight (kg) and litter size (number)

\begin{tabular}{|c|c|c|}
\hline \multirow[b]{2}{*}{ Seasons } & \multicolumn{2}{|l|}{ Parameter } \\
\hline & Birth weight & Litter size \\
\hline$\overline{\text { Cold }}$ & $2.04 \pm 0.08^{\mathrm{b}}$ & $1.16 \pm 0.05^{b}$ \\
\hline Warm & $2.94 \pm 0.13^{\mathrm{a}}$ & $1.61 \pm 0.03^{\circ}$ \\
\hline
\end{tabular}

Table 2: Impact of season on age at 1st kidding and kidding interval (month)

\begin{tabular}{|c|c|c|}
\hline \multirow[b]{2}{*}{ Seasons } & \multicolumn{2}{|l|}{ Parameter } \\
\hline & Age at 1st kidding & Kidding interval \\
\hline$\overline{\text { Cold }}$ & $13.48 \pm 0.22^{\mathrm{a}}$ & $8.16 \pm 0.32^{b}$ \\
\hline Warm & $10.37 \pm 0.31^{\mathrm{b}}$ & $9.13 \pm 0.24^{\mathrm{a}}$ \\
\hline
\end{tabular}


J. Anim. Vet. Adv., 18 (8): 256-259, 2019

Table 3: Variables inputs of enterprise budget for sheep production (EGP)

\begin{tabular}{llcc}
\hline \multicolumn{1}{c}{ Mean \pm SE } & $\begin{array}{l}\text { \% from } \\
\text { total cost }\end{array}$ & $\begin{array}{l}\text { Benefit/ } \\
\text { cost ratio }\end{array}$ \\
\hline Lariables & $20000 \pm 250.34$ & 47.2 & \\
Feed/head/year & $1700.37 \pm 131.67$ & 42.5 & \\
Disinfectant/year & $1042.13 \pm 158.53$ & 2.46 & \\
Vaccine/year & $1534.00 \pm 909.37$ & 3.62 & \\
Drugs/year & $1721.23 \pm 160.12$ & 4.00 & 1.57 \\
Number of flock & $20.00 \pm 3.85$ & & \\
Total variable cost/year & $42297.36 \pm 1730$ & & \\
Total revenue/year & $39456 \pm 1521.22$ & & \\
\hline
\end{tabular}

Table 4: Relationship between demo-graphic characters and profit

\begin{tabular}{ll}
\hline Variables & Values \\
\hline $\mathrm{t}$ & $(9.06)^{* *}+(6.19)^{* *}$ \\
$\mathrm{~F}$ & $211.45^{* *}$ \\
$\mathrm{R}^{-2}$ & 0.31 \\
\hline$* *$ Significant at $(\mathrm{p}<0.01) ; \mathrm{X}_{1}=$ Education level, $\mathrm{X}_{2}=$ Producer age; \\
Function, Log Profit $=5.53+3.42 \log \mathrm{X}_{1}+2.87 \log \mathrm{X}_{2}$
\end{tabular}

Table 5: Explains elasticity for the demographic characters affecting profitability

\begin{tabular}{lc}
\hline Variables & Elasticity \\
\hline Education level & +1.25 \\
Producer age & +1.82 \\
Total & +3.07 \\
\hline
\end{tabular}

ratio was 1.57(Kenyon et al., 2014) concluded that return on capital in the farming business has been around $1 \%$ per annum. However, property values have increased by around $10 \%$ offsetting the low return on capital from farming sheep.

Impact of demo-graphic characters on profitability of sheep farms: Production function estimated in logarithmic form that is more accurate to demonstrate and determine the best accurate regression function to describe the relationship between profitability (profit) as dependent variable and demo-graphic characters (education level and producer age) as independent.

The results revealed that function was highly significant $(\mathrm{p}<0.01)$ and about $31 \%$ in profit changes were attributed to the changes in demo-graphic characters. As concluded in Table 4 and 5 , the elasticity of education level was about $(+1.25)$ that means as the education level increase by about $10 \%$ resulted in increase of total profit by $12.5 \%$. Meanwhile, the elasticity of producer age was about $(+1.82)$ that means the increase in age of producer by $10 \%$ resulted in increase of total profit by $18.2 \%$. These results may be owed to that education level has a positive role in adoption of the new technology and breeding programs in sheep farms also producer age has a positive effect on profitability and productivity through gained experience and decisions taken in the policy of production.

Effect of reproductive efficiency indices on profitability of sheep: The results in Table 6 and 7
Table 6: Relationship between functions and profit

Function

\begin{tabular}{|c|c|c|}
\hline t-values & F-value & $\mathrm{R}^{-2}$ \\
\hline $\begin{array}{l}-(9.65)^{* *},-(9.11)^{* *} \\
-(10.41)^{* *},-(7.89)^{* *}\end{array}$ & $134.98 * *$ & 0.67 \\
\hline \multicolumn{3}{|c|}{$\begin{array}{l}-(10.41) * *,-(7.89) * * \\
* * \text { Significant at }(\mathrm{p}<0.01) \quad \mathrm{X}_{1}=\text { Age at 1st kidding, } \mathrm{X}_{2}= \\
\text { Service/conception; } \mathrm{X}_{3}=\text { Days open; } \mathrm{X}_{4}=\text { Kidding interval; Log } \\
\text { profit }=41.543-0.21 \log \mathrm{X}_{1}-0.182 \log _{2}-0.351 \log \mathrm{X}_{3}-0.462 \log \mathrm{X}_{5}\end{array}$} \\
\hline \multicolumn{3}{|c|}{$\begin{array}{l}\text { Table 7: Explains the different elasticity for the independent variables } \\
\text { affecting profitability }\end{array}$} \\
\hline Variables & & Elasticity \\
\hline Age at first kidding & & -0.21 \\
\hline Service per conception & & -0.18 \\
\hline Days open & & -0.35 \\
\hline Kidding interval & & -0.46 \\
\hline
\end{tabular}

revealed that the logarithmic production function was highly significant $(\mathrm{p}<0.01)$ and about $67 \%$ from the changes profitability were attributed to the changes in reproductive efficiency indices.

As illustrated in Table 7, the average elasticity of age at first kidding was about (-0.21), meaning that the increase in age at first kidding by about $10 \%$ resulted in decrease profitability by $2.1 \%$. Moreover, the average elasticity of service per conception was about $(-0.18)$, meaning that the increase in number of service per conception by $10 \%$ resulted in decrease of profitability by $1.8 \%$.

The average elasticity of days open was about $(-0.35)$, meaning that the increase in days open by $10 \%$ resulted in decrease of profitability by $3.5 \%$. Furthermore, the average elasticity of kidding interval was about (-0.46), meaning that the increase in kidding interval by $10 \%$ resulted in decrease of profit by $4.6 \%$.

\section{CONCLUSION}

The results of the study revealed that warm season had higher parameters for birth weight, litter size and kidding interval than cold season as recorded $2.91 \mathrm{~kg}$, 1.61 and 9.13 months. The manager characters has a significant effect on production of sheep farms as about $31 \%$ in production changes were attributed to the changes in demo-graphic characters as education level and age of producer.

\section{REFERENCES}

Al-Azzawi, W.A.R., R. Kassem, Z. Abdo, A. Duba and I. Al-Herck, 2006. Production performance, some non-genetic factors affecting litter size traits, milk yield in Awassi ewes. Proceedings of the 1st International Conference on Enhancement of Small Ruminant Production Vol. 1, February 7-9, 2006, University of Cairo, Giza, Egypt, pp: 9-32. 
Armbruster, T., K.J. Peters and T. Metz, 1991. Sheep production in the humid zone of West Africa: II Growth performance and liveweight of sheep in improved and traditional production systems in Cote d'Ivoire. J. Anim. Breed. Genet., 108: 210-219.

Atallah, S.T., 1997. Economic and productive efficiency of veterinary management in dairy farms. Ph.D Thesis, Veterinarian Medicine, Alexandria University, Alexandria, Egypt.

De Queiroz, J.S., N. Gutierrez-Aleman and F.A.P. de Leon, 1986. The ecology and management of small ruminant production systems in the Sertao of Ceara, in the Northeast of Brazil. Agric. Syst., 22: 259-287.

Ebangi, A.L., L.N. Nwakalor, D.A. Mbah and D. Abba, 1996. Factors affecting the birth weight and neonatal mortality of Massa and Fulbe sheep breeds in a hot and dry environmental, Cameroon. Rev. Elev. Med. Vet. Pays. Trop., 49: 349-353.

Galal, S., F. Abdel-Rasoul, M.R. Anous and I. Shaat, 2005. On-Station Characterization of Small Ruminant Breeds in Egypt. In: Characterization of Small Ruminant Breeds in West Asia and North Africa, Iniguez, L.C. (Ed.). Vol. 2, ICARDA, Aleppo, Syria, pp: 141-193.
Kenyon, P.R., A.N. T hompson and S.T. Morris, 2014. Breeding ewe lambs successfully to improve lifetime performance. Small Rumin. Res., 118: 2-15.

Long, T.E., D.L. Thomas, R.L. Fernando, J.M. Lewis and U.S. Garrigus et al., 1989. Estimation of individual and maternal heterosis, repeatability and heritability for Ewe productivity and its components in Suffolk and Targhee sheep 1. J. Anim. Sci., 67: 1208-1217.

Odunsi, A.A., V.A. Togun and I.O. Oladunyoye, 2005. Introduction to Animal Production and Processing. Oluseyi Press Limited, Ibadan, Nigeria,.

Okunlola, J.O., 2000. Socio-economic constraint in sheep and goat production in Ekiti and Ondo State. MSc Thesis, University of Ibadan, Ibadan, Nigeria.

Omar, M.A.E., 2009. Economic study on the productive and reproductive efficiency in dairy farms in relation to veterinary management. $\mathrm{PhD}$ Thesis, Zagazig University, Zagazig, Egypt.

Safilios-Rothschild, C., 1983. Women in sheep and goat production and marketing. FAO, Rome, Italy.

Seyoum, S., 1992. Economics of small ruminant meat production and consumption in Sub-Saharan Africa. Intl. Livestock Centre Afr., 2: 15-26.

Souza, N.J., A.N. Gutierrez and M.M. Amin, 1984. Revista de Economia Rural. Vol. 22, University of Texas, Austin, Texas,. 